\title{
EL USO DE LAS TECNOLOGÍAS DE LA INFORMACIÓN Y COMUNICACIÓN EN LA EDUCACIÓN
}

\section{Jorge VILLALBA ARIAS ${ }^{1}$.}

${ }^{1}$ Jefe del Departamento de Extensión Universitaria e Investigaciones, Filial Santa Rosa del Aguaray, Facultad de Ciencias Médicas, Universidad Nacional de Asunción, San Lorenzo - Paraguay. Editor Asociado, Revista Medicina Clínica y Social.

Cómo citar este artículo: Villalba Arias J. El uso de las Tecnologías de la Información y Comunicación en la educación. Medicina Clínica y Social. 2017;1(2):103-104.

\section{Estimados lectores,}

Las Tecnologías de la Información y la Comunicación (TIC) son un conjunto de servicios, redes, programas y aparatos que tienen como fin la mejora de la calidad de vida de las personas dentro de un entorno, y que se integran a un sistema de información interconectado y complementario.

Las TIC se imaginan como el universo de dos conjuntos, representados por las tradicionales Tecnologías de la Comunicación (constituidas principalmente por la radio, la televisión y la telefonía convencional) y por las Tecnologías de la Información (caracterizadas por la digitalización de las tecnologías de registros de contenidos). Las TIC son herramientas teóricas y conceptuales, soportes y canales que procesan, almacenan, sintetizan, recuperan y presentan información de la forma más variada (1).

Las TIC tienen una influencia cada vez mayor en la forma de comunicarse, el aprendizaje y la vida. El desafío consiste en utilizar eficazmente estas tecnologías para que estén al servicio de los intereses del conjunto de los estudiantes y de toda la comunidad educativa (2).

Las TIC pueden contribuir al fortalecimiento y la gestión de la planificación educativa democrática y transparente. Las tecnologías de la comunicación pueden ampliar el acceso al aprendizaje, mejorar la calidad y garantizar la integración. Donde los recursos son escasos, la utilización prudente de materiales de fuente abierta por medio de las TIC puede contribuir a superar los atascos que genera la tarea de producir, distribuir y actualizar los manuales escolares (3).

Por su parte, el aprendizaje móvil (llamado en inglés m-learning) ofrece métodos modernos de apoyo al proceso de aprendizaje mediante el uso de instrumentos móviles, tales como los ordenadores portátiles y las tabletas informáticas, los lectores MP3, los teléfonos inteligentes (smartphones) y los teléfonos móviles.

El aprendizaje móvil, personalizado, portátil, cooperativo, interactivo y ubicado en el contexto, presenta características singulares que no posee el aprendizaje tradicional mediante el uso de instrumentos electrónicos (e-learning). En el primero, se hace hincapié en el acceso al conocimiento en el momento adecuado, ya que por su conducto la instrucción puede realizarse en cualquier lugar y en todo momento. En tanto que el segundo, ayuda al aprendizaje formal e 
informal, y posee un enorme potencial para transformar las prestaciones educativas y la capacitación (4).

En este segundo número de Medicina Clínica y Social, Barrios y colaboradores abordan, a través de un completo artículo de revisión, las herramientas informáticas para el estudiante de medicina investigador. Una detenida lectura del mismo actualizará nuestros conocimientos respecto a los TIC y nos permitirá dar mejor uso a herramientas diarias de las que, probablemente, no estamos utilizando todo su potencial.

Concluyendo, me hago eco de las palabras que Kofi Annan, entonces Secretario General de la Organización de las Naciones Unidas, pronunciara en los actos inaugurales de la Cumbre Mundial sobre la Sociedad de la Información de 2003: "Las tecnologías de la información y la comunicación no son ninguna panacea ni fórmula mágica, pero pueden mejorar la vida de todos los habitantes del planeta. Se dispone de herramientas para llegar a los Objetivos de Desarrollo del Milenio, de instrumentos que harán avanzar la causa de la libertad y la democracia y de los medios necesarios para propagar los conocimientos y facilitar la comprensión mutua. Todos tenemos ese potencial. La Cumbre deberá aprovecharlo" (5).

\section{CONFLICTOS DE INTERÉS Y FUENTE DE FINANCIACIÓN}

El autor declara no poseer conflictos de interés. Fuente de financiación: ninguna.

\section{REFERENCIAS BIBLIOGRÁFICAS}

1. Cenich G, Santos G. Propuesta de aprendizaje basado en proyectos y trabajo colaborativo: experiencia de un curso en línea. Revista Electrónica de Investigación Educativa 2010;7(2):1-18. URL.

2. Mata F. Universidad y TIC. Implicaciones prácticas. Congreso Europeo de Aplicación de las Nuevas Tecnologías a la Enseñanza. Barcelona.

3. Lara P, Duart JM. Gestión de contenidos en el e-learning: acceso y uso de objetos de información como recurso estratégico. Revista de Universidad y Sociedad del Conocimiento 2013;2(2):6-16. URL.

4. Cabello J, Antón P. Conversaciones con el profesorado: un estudio en cuatro universidades españolas sobre el Espacio Europeo y el uso de las TIC. Revista de Educación 2005;337:149-167. URL.

5. Unión Internacional de Telecomunicaciones [Internet]. Ginebra: Unión Internacional de Telecomunicaciones; c2003 [citado 26 ago 2017]. Mensaje de Kofi Annan, Secretario General de las Naciones Unidas [aprox. 1 pantalla]. Disponible en: http://www.itu.int/net/wsis/messages/annan-es.html 


\section{THE USE OF INFORMATION AND COMMUNICATION TECHNOLOGIES IN EDUCATION}

\section{Jorge VILLALBA ARIAS ${ }^{1}$.}

${ }^{1}$ Head of the University Extension and Research Department, Santa Rosa Campus, School of Medical Sciences, National University of Asunción, Santa Rosa del Aguaray - Paraguay. Associate Editor, Journal Medicina Clínica y Social.

How to cite this article: Villalba Arias J. El uso de las Tecnologías de la Información y Comunicación en la educación. Medicina Clínica y Social. 2017;1(2):103-104.

\section{Dear Readers,}

Information and Communication Technologies (ICTs) are a set of services, networks, software and devices that aim to improve the quality of life of people within an environment, and which are integrated into an interconnected and complementary information system.

ICTs are imagined as the universe of two sets, represented by the traditional Communication Technologies (consisting mainly of radio, television and conventional telephony) and Information Technology (characterized by the digitalization of the technologies of registers of contents). ICTs are theoretical and conceptual tools, channels that process, store, synthesize, retrieve and present information in the most varied way (1).

ICTs have a growing influence on communication, learning and life. The challenge is to use these technologies effectively to serve the interests of all students and the entire educational community (2).

ICTs can contribute to the strengthening and management of democratic and transparent educational planning. Communication technologies can expand access to learning, improve quality and ensure integration. Where resources are scarce, the prudent use of open source materials through ICTs can help overcome the bottlenecks of the production, distribution and updating of school textbooks (3).

On the other hand, mobile learning (m-learning) offers modern methods of supporting the learning process through the use of mobile devices, such as laptops and tablets, MP3 players, smartphones and mobile phones.

Personalized, portable, cooperative, interactive and located in context m-learning, presents unique characteristics that traditional learning through the use of electronic instruments (elearning) does not possess. In the first, emphasis is placed on access to knowledge at the right time, since through it instruction can be done anywhere and at all times. While the latter supports formal and informal learning and has enormous potential for transforming educational provision and training (4).

In this second issue of Medicina Clínica y Social, Barrios et al approach, through a complete review article, the computer tools for the researcher medical student. A careful reading of it 
will update our knowledge of ICTs and allow us to make better use of everyday tools that we are probably not using to their full potential.

In conclusion, I echo the words of Kofi Annan, then Secretary-General of the United Nations, at the opening events of the World Summit on the Information Society of 2003: "Information and communication technologies are no panacea or magic formula, but can improve the lives of all the inhabitants of the planet. Tools are available to achieve the Millennium Development Goals, instruments that will advance the cause of freedom and democracy and the means to propagate knowledge and facilitate mutual understanding. We all have that potential. The Summit should take advantage of it" (5).

\section{CONFLICTS OF INTEREST AND FUNDING}

Conflicts of interest: none. Funding source: none.

\section{REFERENCES}

1. Cenich G, Santos G. Propuesta de aprendizaje basado en proyectos y trabajo colaborativo: experiencia de un curso en línea. Revista Electrónica de Investigación Educativa 2010;7(2):1-18. URL.

2. Mata F. Universidad y TIC. Implicaciones prácticas. Congreso Europeo de Aplicación de las Nuevas Tecnologías a la Enseñanza. Barcelona.

3. Lara P, Duart JM. Gestión de contenidos en el e-learning: acceso y uso de objetos de información como recurso estratégico. Revista de Universidad y Sociedad del Conocimiento 2013;2(2):6-16. URL.

4. Cabello J, Antón P. Conversaciones con el profesorado: un estudio en cuatro universidades españolas sobre el Espacio Europeo y el uso de las TIC. Revista de Educación 2005;337:149-167. URL.

5. Unión Internacional de Telecomunicaciones [Internet]. Ginebra: Unión Internacional de Telecomunicaciones; c2003 [citado 26 ago 2017]. Mensaje de Kofi Annan, Secretario General de las Naciones Unidas [aprox. 1 pantalla]. Disponible en: http://www.itu.int/net/wsis/messages/annan-es.html 